\title{
BIOCHEMICAL STUDIES ON THE EFFECT OF Metarhizium anisopliae VAR acridum INFECTION IN THE DESERT LOCUST, Schistocerca gregaria FORSKAL
}

\author{
Eid, M. A. A.*; G. H. Sewify*; Hanan
}

T. A. Abdel-Fattah ${ }^{\star *}$ and S. M. Said ${ }^{\star}$

* Department of Entomology \& Pesticides, Fac. Agric., Cairo University

** Department of Locust and Grasshopper, Plant Protection Research Institute, Agriculture Research Center.

\begin{abstract}
Fifth instar nymphs of the desert locust Schistocerca gregaria Forskal were topically treated with $5 \mu \mathrm{l}$ of an oil-based spore suspension of the entomopathogenic fungus Metarhizium anisopliae var acridum. Haemolymph samples were collected from both control and treated insects every 24 hours starting from day 2 after the treatment.

Estimation of total protein, total carbohydrate, total lipids and cholesterol were carried out. The results showed that the haemolymph content of the treated insects was highly affected and all the studied parameters were lower than in the control insects the decrease in the haemolymph content increased by increasing the postinoculation period.

Keywords: Schistocerca gregaria, Entomopathogenic, Metarhizium anisopliae var acridum, Haemolymph, Protein, Carbohydrate, Lipid, Cholesterol.

\section{INTRODUCTION}

Locusts and grasshoppers (Orthoptera: Acrididae) represent perhaps the most conspicuous of all insect pests and are the most abundant insects of dry grassland and desert. When populations of these insects buildup, certain species exhibit gregarious and migratory behavior, leading to the formation of spectacular swarms (Showler and Potter, 1991). Consideration of Acrididae population dynamics is useful in evaluating the potential for biological control (Lockwood and Ewen, 1997). Indigenous Deuteromycete such as Beauveria spp. and Metarhizium spp fungi have considerable potential as microbial control agents because they are genetically stable and can be produced cheaply in large quantities. (Prior and Greathead, 1989).The aim of integrated biological control of Acrididae pests is to develop acceptable alternative nonchemical methods for controlling locusts and grasshoppers. The existing control measures still rely heavily on chemical pesticides which are the only reliable method in cases of severe infection (Johnson et al. 1988). The purpose of this study is to evaluate the effect of the entomopathogenic fungus Metarhizium anisopliae var acridum against the desert locust Schistocerca gregaria through studying its effect on the haemolymph of survivors.
\end{abstract}

\section{MATERIALS AND METHODS}

\section{1- Rearing of test insects}

Nymphal instars of the desert locust Schistocerca gregaria, Forskal (Orthoptera: Acrididae) 2 days after ecdysis were used in all experiments. The individuals were taken from the sock culture maintained for several 
Eid, M. A. A. et al.

generations at the locust research section, plant protection research institute (PPRI), A.R.C., Dokki, Giza. . The insects were reared in the laboratory according to (Robert, et al., 2002) in wooden framed cages measuring $(60 \times 60 \times 70 \mathrm{~cm})$. The cages sides were made of wire gauze with glass top and a small door in the front side, for daily routine feeding, cleaning and handing. A sand layer of $20 \mathrm{~cm}$ deep was spread in the bottom of each cage for egg lying, and kept until hatching. Each cage was illuminated and heated by a100 watt electric bulb. Nymphs were transferred to other cages measured $(100 \times 100 \times 120 \mathrm{~cm})$ without a sand layer for rearing the progeny. All cages were placed on a large table and a suitable container was filled with water and placed under every table leg. The electric wires were painted with grease to protect nymphs from ants attack. The daily routine work includes removing the previous uneaten food, faces and dead nymphs before introducing the fresh food. Both hoppers and adults were fed on brunches of Berseem, Trifolium alexandrinum and dry wheat bran fortified with $5 \%$ yeast powder as a source of vitamin $\mathrm{B}_{1}$. Fortified bran was introduced in Petri dishes. The locust's cages were kept at $32 \pm 2{ }^{\circ} \mathrm{C}$ and $30-50 \%$ R.H.). When the cages were empty due to the termination of the life cycle for each generation or when the locusts were removed for experimental purposes, they were disinfected by a diluted solution of an antiseptic agent to avoid contamination with harmful microorganisms.

\section{2- The entomopathogenic fungus}

The entomopathogenic fungus used during the study was Metarhizium anisopliae var acridum (=Metarhizium flavoviridae Driver, et al., 2000) isolate (IMI 330189) originally obtained in 1988 from Ornithacris cavroisi (Finot) (Orthoptera: Acrididae) from the International Agricultural Center, Nairobi, Kenya. It is specific to locusts and grasshopper conidia of fungus were suspended in cotton seed oil and the resulting spore suspension was used in inoculating insects with dose $5 \times 10^{7}$ Spores $/ \mathrm{ml}$.

3- Characterization of the haemolymph of the $5^{\text {th }}$ nymphal instar after infection with an entomopathogenic fungus

3-1- Inoculation of insects

Fifth instar nymphs 2-3 days old after molting were taken for experiments under laboratory conditions. Five hundred nymphs (250 treatments +250 controls) were divided into five replications for every experiment. Locusts were chilled at $4^{\circ} \mathrm{C}$ for $1 \mathrm{~h}$ prior to topical application beneath the dorsal pronotal shield with $5 \mu$ l of fungus formulation for the treated nymphs and $5 \mu \mathrm{l}$ cotton seed oil for control nymphs using a micropipette applicator (Bateman, et al., 1993). Nymphs were kept in cages $(25 \times 25 \times 60 \mathrm{~cm})$ at $30 \pm 2^{\circ} \mathrm{Cand} 30-50 \%$ R.H., with a fluorescent lamp as a light source. The control insects were placed in other cages under the same conditions in $16 \mathrm{~h}$ light and $8 \mathrm{~h}$ dark (Robert et al. 2002). Samples of the haemolymph were taken at different intervals of 2, 3, 4, 5, and 6 days after inoculation. (Metaweh, et al. 2001a).

3-2- Samples collection and purification

The haemolymph was collected through a fine puncture in the hind leg membrane and transferred into clean dry centrifuge tubes. Few crystals of phenylthiourea were added to prevent melanization before analysis. A known 
volume of the collected haemolymph $(0.1 \mathrm{ml})$ was diluted up to $2 \mathrm{ml}$ with saline solution and purified by centrifugation to remove blood cells and pigments. Then the filtrate was collected for blood analysis (El Gawhary, 1997).

\section{3-3- Determination of total carbohydrate}

\section{3-3-1- Reagents}

Total carbohydrates were estimated according to Trinder, (1969).

Solution (1): phosphate buffer (170 m mol/L.ph 7.0). G.O.D. (glucose oxidase) $(>5 \mu \mathrm{l} / \mathrm{ml}$ ). P.O.D. (peroxidase) $(>3 \mu \mathrm{l} / \mathrm{ml}$ ) amino phenazone $(0.28 \mathrm{~m} . \mathrm{mol} / \mathrm{L})$ and phenol $(16 \mathrm{~m} \mathrm{~mol} / \mathrm{L})$.

Standard solution has a concentration of $100 \mathrm{mg}$ glucose $/ 100 \mathrm{ml}$.

A known volume of solution (1) (1-2.5 ml) was added alone into $(0.02$ $\mathrm{ml}$ ) the standard solution and mixed together to prepare the standard. For sample preparation, $2.5 \mathrm{ml}$ of solution (1) were mixed with $0.02 \mathrm{ml}$ of haemolymph filtrate. The tubes were shaked well and incubated at $37^{\circ} \mathrm{C}$ for $15 \mathrm{~min}$. The absorbance of the sample (A sample) and that of the standard (A standard) were read $505 \mathrm{~nm}$ using $1 \mathrm{~cm}$ cuvette.

\section{3-3-2- Calculation}

$\mathrm{mg}$ glucose $/ 100 \mathrm{ml}$ filtrate haemolymph $=(A$ sample $/ \mathrm{A}$ standard $) \mathrm{X}$ 100

\section{3-4- Determination of total lipids}

Total lipids were estimated according to the modified methods of Knight, et al., (1972).

\section{3-4-1- Phospho-vaniline reagent}

Pure vaniline $(0.6 \mathrm{gm})$ was dissolved in $10 \mathrm{ml}$ ethyl alcohol and the volume was completed to $100 \mathrm{ml}$ with distilled water. Phosphoric acid $(400 \mathrm{ml})$ was then added. The solution was stored in a dark glass bottle at room temperature.

\section{3-4-2- Standard lipid solution}

A known weight of lipid ( $5 \mathrm{mg} / \mathrm{ml})$ consists of, Oleic acid and Palmitic acid in a ratio of $7: 3$ was prepared by dissolving Oleic acid ( $350 \mathrm{mg}$ ) and Palmitic acid ( $15 \mathrm{mg})$ in absolute ethanol $(100 \mathrm{ml})$.

A known volume of haemolymph filtrate $(0.1 \mathrm{ml})$ was added to conc. Sulphuric acid $(5 \mathrm{ml})$ in a test tube and heated in a boiling water bath for 10 min. After cooling to room temperature. The digest $(0.1 \mathrm{ml})$ was added to Phospho-vaniline reagent $(6.0 \mathrm{ml})$ after $45 \mathrm{~min}$. The developed color was measured in Bush and Lamp spectrophotometer at $525 \mathrm{~nm}$. Distilled water $(0.1 \mathrm{ml})$ was used for blank. The standard lipids solution $(0.2 \mathrm{ml})$ was used and treated in the same manner as the unknown.

\section{3-4-3- Calculation}

$$
\mathrm{mg} \mathrm{lipid} / 100 \mathrm{ml} \text { filtrate haemolymph }=(\text { A sample } / A \text { standard }) \times 100
$$

\section{3-5- Determination of total protein}

Protein content was determined by Biuret reagent according to the method described by Gornall, et al., (1949) as follows:

\section{3-5-1- Reagent}

The Biuret reagent was prepared by dissolving 1.5gm copper sulphate ( CuSo $4.5 \mathrm{H} 2 \mathrm{O}$ ) and $6 \mathrm{mg}$ Sodium potassium tartarate ( $\mathrm{NaKC}_{4}$ $\mathrm{H}_{4} \mathrm{O}_{6} .4 \mathrm{H}_{20}$ ) in $500 \mathrm{ml}$ distilled water and mixed thoroughly with $300 \mathrm{ml}$ of $10 \%$ (W/V ) Sodium hydroxide ( Carbonate free ) and the volume was completed 
Eid, M. A. A. et al.

to 1 liter. Potassium iodide (1gm) was added and the reagent was stored in a waxed or plastic bottle.

\section{3-5-2- Standard solution of protein}

The standard solution was prepared by dissolving $6 \mathrm{gm}$ Albumin protein in $100 \mathrm{ml}$ distilled water

A volume of $0.1 \mathrm{ml}$ of the haemolymph filtrate was mixed with $5 \mathrm{ml}$ of the Biuret reagent in a test tube and incubated for $30 \mathrm{~min}$ at $20-25 \mathrm{C}^{\circ}$. The absorbance (A) was measured at a wavelength $546 \mathrm{~nm}$ using $1 \mathrm{~cm}$ light path cuvette.

\section{3-5-3- Calculation} 100

$\mathrm{mg}$ protein $/ 100 \mathrm{ml}$ filtrate haemolymph $=(\mathrm{A}$ sample $/ \mathrm{A}$ standard $) \mathrm{x}$

\section{3-6- Determination of total cholesterol}

Total cholesterol was determined by the enzymatic colourimetric method of Richmond, (1973). All reagents used in this determination were supplied by Ames Division Miles Lab. Inc, England.

\section{3-6-1- Reagents}

Solution (1) contains buffer-enzyme-chromogents.

Solution (2) contains Phenol.

Solution (3) one volume of solution (1) + one volume of solution (2). Where one liter of solution (3) contains the following, phosphate buffer 10 $\mathrm{mmol} \mathrm{PH}=7.7$ Cholesterol ester hydrolase $\geq 140 \mu \mathrm{l}$. cholesterol oxidase $\geq$ $80 \mu$.peroxides $\geq 500 \mu$. Phenol $10 \mathrm{mmol}, 4$ amino-phenazone $0.5 \mathrm{mmol}$ potassium ferrocyanide $2 \mu \mathrm{mol}$ and Sodium cholate $3 \mathrm{mmol}$.

Solution (4): is the standard solution

The reagents were kept at $5^{\circ} \mathrm{C}$ for one month.

Solution (1) and (2) were mixed instantly before use.

\section{3-6-2- Procedure}

Volume (2-2.5 ml) of solution was pipetted into a test tube to form the blank. The standard test tube was made by placing the standard solution (3) $(2.5 \mathrm{ml})$ and solution (4) $(0.02 \mathrm{ml})$ into a test tube. The standard solution was added to this tube and $0.2 \mathrm{ml}$ of the unknown sample. After well mixing the test tubes were incubated at $37 \mathrm{C}^{\circ}$ for 10 minutes or at room temperature for at least 30 minutes and measured at wave length of $410 \mathrm{~nm}$ cuvette.

\section{3-6-3- Calculation}

$\mathrm{mg}$ cholesterol/100 $\mathrm{ml}$ filtrate haemolymph $=($ A sample $/ \mathrm{A}$ standard $) \mathrm{x}$ 100

\section{5- Statistical analysis}

Data were analyzed by analysis of variance (ANOVA) means, within row, bearing different subscripts are significantly different $(P<0.05)$.

\section{RESULTS}

Characterization of the haemolymph of the fifth nymphal instar of desert locust, $S$. gregaria after infection with an entomopathogenic fungus, $M$. anisopliae var acridum was done to investigate the effect of fungal infection on total proteins, carbohydrates, lipids and cholesterol. 


\section{Effect on Protein levels}

A dose of $5 \times 10^{7}$ spore $/ \mathrm{ml}$ of the entomopathogenic fungus, $M$. anisopliae var acridum was topically applied on $5^{\text {th }}$ nymphal instar of the desert locust, $S$. gregaria and the chemical analysis of the haemolymph was carried out in period from day 2 until day 6 after treatment.

Table (1): Determination of total protein of the 5th nymphal instar of desert locust, $S$. gregaria after infection with an

\begin{tabular}{|c|c|c|}
\hline Days & Controls & Treatments \\
\hline 2nd & $4106 \pm 45 \mathrm{a}$ & $4040 \pm 36 \mathrm{a}$ \\
\hline 3rd & $5623 \pm 166 \mathrm{a}$ & $5053 \pm 60 \mathrm{~b}$ \\
\hline 4th & $6226 \pm 65 \mathrm{a}$ & $4920 \pm 150 \mathrm{~b}$ \\
\hline 5th & $5420 \pm 160 \mathrm{a}$ & $4165 \pm 37 \mathrm{~b}$ \\
\hline 6th & $4660 \pm 40 \mathrm{a}$ & $4110 \pm 98 \mathrm{~b}$ \\
\hline
\end{tabular}

$b=$ significant

entomopathogenic fungus, $M$. anisopliae var acridum

Table (1) showed the effect of one dose of entomopathogenic fungus $\left(5 \times 10^{7}\right.$ spores $\left./ \mathrm{ml}\right)$ on the resulting $5^{\text {th }}$ nymphal instar after administration on 2-day old nymph of the last stadium. The entomopathogenic fungus caused a decrease in the haemolymph protein content compared to that of the control. There was significance difference in the total protein content in both the treated and control insects in $2^{\text {nd }}$ day of application but the difference appeared starting from $3^{\text {rd }}$ day of application and the reduction in haemolymph protein content continued by time even $6^{\text {th }}$ day of application to reach minimum values at the end of the experiment.

\section{Effect on total Carbohydrate levels}

The effect of the entomopathogenic fungus dose $\left(5 \times 10^{7}\right.$ spores $\left./ \mathrm{ml}\right)$ on total carbohydrate content in the inoculated $5^{\text {th }}$ nymphal instar when applied on 2-day old nymphs are summarized in table (2).

Table (2): Determination of total carbohydrate of the 5th nymphal instar of desert locust, $S$. gregaria after infection with an entomopathogenic fungus, $M$. anisopliae var acridum.

\begin{tabular}{|c|c|c|}
\hline Days & Control & Treatment \\
\hline 2nd & $336 \pm 6 \mathrm{a}$ & $332 \pm 12 \mathrm{a}$ \\
\hline 3rd & $411 \pm 7 \mathrm{a}$ & $396 \pm 5 \mathrm{~b}$ \\
\hline 4th & $380 \pm 07 \mathrm{a}$ & $346 \pm 10 \mathrm{~b}$ \\
\hline 5th & $392 \pm 6 \mathrm{a}$ & $346 \pm 10 \mathrm{~b}$ \\
\hline 6th & $538 \pm 9 \mathrm{a}$ & $318 \pm 8 \mathrm{~b}$ \\
\hline b= significant & a= non significant means \pm S.D. (P<0.05).
\end{tabular}

It was found that carbohydrate levels were decreased markedly in the treated $5^{\text {th }}$ nymphal instar than that of the untreated at all periods post inoculation. The values of carbohydrate contents during periods of application (from $2^{\text {nd }}$ to $6^{\text {th }}$ day after application) in treated nymphs $396,346,346$ and 318 
Eid, M. A. A. et al.

$\mathrm{mg} / 100 \mathrm{ml}$ haemolymph but in control were $411,380,392$ and $538 \mathrm{mg} / 100 \mathrm{ml}$ haemolymph.

\section{Effect on Lipids levels}

The effect of the entomopathogenic fungus ( $5 \times 10^{7} \mathrm{spores} / \mathrm{ml}$ ) on total lipid contents in the inoculated $5^{\text {th }}$ nymphal instar when applied within the second day of this instar are summarized in table (3) . On $2^{\text {nd }}$ day post inoculation there were no significant differences between the treated and the untreated nymphs but on $3^{\text {rd }}, 4^{\text {th }}, 5^{\text {th }}$ and $6^{\text {th }}$ day, significant differences were noticed the values of total lipids in infected nymphs were $171,145,143$ and $105 \mathrm{mg} / 100 \mathrm{ml}$ haemolymph but in control were $214,184,210$ and $187 \mathrm{mg} /$ $100 \mathrm{ml}$ haemolymph. From these results, it was observed thatthe entomopathogenic fungus application to the 5th instar nymphs caused continuous reduction in the total lipid content in the haemolymph.

Table (3): Determination of total lipid of the 5th nymphal instar of desert locust, S. gregaria after infection with an entomopathogenic fungus, M. anisopliae var acridum

\begin{tabular}{|c|c|c|}
\hline Days & Control & Treatment \\
\hline 2nd & $19.8 \pm 1.52 \mathrm{a}$ & $15.66 \pm 0.56 \mathrm{~b}$ \\
\hline 3rd & $18.56 \pm 0.4 \mathrm{a}$ & $11.76 \pm 1.07 \mathrm{~b}$ \\
\hline 4th & $15.5 \pm 0.3 \mathrm{a}$ & $9 \pm 0.3 \mathrm{~b}$ \\
\hline 5th & $19.1 \pm 0.6 \mathrm{a}$ & $8.4 \pm 0.5 \mathrm{~b}$ \\
\hline 6th & $11.4 \pm 0.52 \mathrm{a}$ & $7.43 \pm 0.49 \mathrm{~b}$ \\
\hline b= significant & a= non significant & \multicolumn{2}{|c|}{ means \pm S.D. (P<0.05). }
\end{tabular}

\section{Effect on Cholesterol levels}

The values of total cholesterol extracted from the haemolymph of 5th nymphal instar of desert locust infected with the entomopathogenic fungus, $M$. anisopliae var acridum in table (4) showed significant differences between treated and untreated nymphs during $2^{\text {nd }}, 3^{\text {rd }}, 4^{\text {th }}, 5^{\text {th }}$ and $6^{\text {th }}$ days of application.

Table (4): Determination of total cholesterol of the 5th nymphal instar of

\begin{tabular}{|c|c|c|}
\hline \multicolumn{1}{|c|}{ desert locust, S. gregaria after infection with an } \\
\hline Days & Control & Treatment \\
\hline 2nd & $230 \pm 9 \mathrm{a}$ & $235 \pm 8 \mathrm{a}$ \\
\hline 3rd & $214 \pm 4.1 \mathrm{a}$ & $171 \pm 3.2 \mathrm{~b}$ \\
\hline 4th & $184 \pm 49 \mathrm{a}$ & $145 \pm 11 \mathrm{~b}$ \\
\hline
\end{tabular}

entomopathogenic fungus, $M$. anisopliae var acridum 
J. Agric. Sci. Mansoura Univ., 34 (3), March, 2009

\begin{tabular}{|c|c|c|}
\hline 5th & $210 \pm 7 \mathrm{a}$ & $143 \pm 5.5 \mathrm{~b}$ \\
\hline 6th & $187 \pm 6.3 \mathrm{a}$ & $105 \pm 6 \mathrm{~b}$ \\
\hline S= significant & Ns= non significant $\quad$ means \pm S.D. (P< 0.05).
\end{tabular}

\section{DISCUSSION}

Infection the $5^{\text {th }}$ nymphal instar of the desert locust, $S$. gregaria with the entomopathogenic fungus, $M$. anisopliae var acridum $\left(5 \times 10^{7} \mathrm{spores} / \mathrm{ml}\right)$ during period from day 2 to day 6 of the treatment caused reduction of total protein, total carbohydrate, total lipid and total cholesterol compared with untreated nymphs. These analyses were carried out after 2 days after inoculation because at this time the fungus has invaded the body cavity and reached to the haemolymph (Bateman et al., 1993).

The effect of mycosis on haemolymph protein in the locust could be due either to a direct effect of the fungus through their use and consumption by the germinated spores and hyphal bodies of the fungus for nutrition and the total starvation had no significant effect on the total carbohydrate (Cheeseman and Goldsworthy, 1979). Where efficient mechanisms of carbon assimilation in vivo are likely to be critical for host specificity and virulence. Competition for carbon between the pathogen and host may determine the rate and extent of infection however, the fungal enzymes involved in carbon uptake have not been identified an extracellular trehalase has been purified from invitro cultures of Langenidium spp., a fungal parasite of mosquitoes (Domnas and Warner, 1991).

A decline in the concentration of the major haemolymph storage carbohydrate, Trehalose, during the infection process suggests that this disaccharide is used the entomopathogenic fungus during the colonization of the host (Gillespie et al., 2000b). Although the fungal trehalase was not identified invivo. Interestingly mutants of Metarhizium hypervirulent toward the mosquito Culex pipiens exhibit enhanced starch degrading ability (Al-Aidroos and Seifert, 1980). In light of the substrate preference exhibited by the extracellular-glucosidase purified from $M$. anisopliae (Cobb, 1996). It is possible that the hypervirulent observed towards mosquitoes resulted from increased degradation of glycogen and Trehalose during the invasion of insect tissues the degradation and utilization of Trehalose by the fungus not only depletes a valuable energy reserve of the insect but will also interfere with the osmotic regulation of the insect haemolymph (Gillespie et al., 2000b). Or indirectly to a semi-starved condition brought on by the reduced food intake in infected insects (Seyoum et al., 1994). The latter seems unlikely as 3 days of total food deprivation had no significant effect on blood lipid and carbohydrate, and, in common with Locusta migratoria (Cheeseman and Goldsworthy, 1979) Also The decline observed in infected insects one alternative explanation is that mycosed insects are unable to mobilize lipid from their fat body or that there is so little lipid in their fat bodies that they are unable to maintain plasma levels (Goldsworthy and Mordue, 1973). The 
Eid, M. A. A. et al.

cholesterol is the biosynthesis precursor of ecdysone hormone in insects so, the estimation of the Juvenile hormone mimic role on this metabolite deemed necessary to evaluate its action upon the precursor of moulting hormone (ecdysone ) in S. gregaria (Rees, 1985). These results are agreement with that of (Metaweh et al., 2001a) found that total lipid, total carbohydrate, total protein and total cholesterol in haemolymph of treated-grasshopper, Eurpepocnemis plorans plorans ( $5^{\text {th }}$ instar nymphs) with the entomopathogenic fungus, M. flavoviridae $\left(5 \times 10^{6} \mathrm{spores} / \mathrm{ml}\right)$ decreased on untreated samples. Also (Gillespie et al., 2000a) who found that the desert locust, S. gregaria when inoculated topically with $M$. anisopliae var acridum the total protein and total lipid of the haemolymph decreased during the course of infection moreover And adult desert locust $S$. gregaria 3days after inoculation with the entomopathogenic fungus $M$ anisopliae var acridum ( $4 \mathrm{x}$ $10^{7} \mathrm{spores} / \mathrm{ml}$ ) had significantly less lipid and carbohydrate in the haemolymph than controls this was not due to reduced food intake as 3 days of complete starvation had not effect on haemolymph titers of energy reserves in controls (Seyoum, et al., 2002). And (Sewify and Moursy, 1993) who found that the aphid Brevicoryne brassicae when treated with Verticillium lecanii $\left(10^{7} \mathrm{spores} / \mathrm{ml}\right)$ had significantly lower concentration of total crude lipids compared to the concentration of untreated aphids. in the same way (Boucias and Pendland, 1984) found that whole lipids, polar and hydrocarbon fractions of lipids extracted from lepidopteran cuticle were active in stimulating germ tube formation of Deuteromycetes Nomuraea rileyi also (Latge et al., 1987 ) mentioned that the formation of Ciodioblus obscurus germ tubes were stimulated by lipidoidal extracts of the aphid cuticle. Steel and hall (1985) stated that the fat body is generally regarded the principal site of trehalase biosynthesis in insects. they added that haemolymph trehalase is an important source of energy and chitin biosynthesis. The Haemolymph trehalose decreased significantly during mycosis of locusts by $M$. anisopliae. All these results suggested that this fungus may take advantage of competing nutrient utilization against the insect (Hua et al., 2007). (Polanowski et al., 1997) showed that the desert locust, S. gregaria when treated with the entomopathogenic fungus, $\quad M$. anisopliae the total protein level of the haemolymph decreased during the course of infection. But (Gurwattan et al., 1991) found that Vegetative development of Beauveria bassiana in the haemocoel of the beet armyworm, Spodoptera exigue did not cause significant alterations in the profile of proteins pulse labeling tissue explants revealed that vegetative growth of $B$. bassiana hyphal bodies did not impact the biosynthetic.

Accordingly it could be concluded that the entomopathogenic fungus acted mainly on the haemolymph of the inoculated $5^{\text {th }}$ nymphal instar of the desert locust, S. gregaria causing decrease in protein, carbohydrate, lipid and cholesterol levels.

Finally the entomopathogenic fungus, M. anisopliae var acridum could effect the energy reserves in the haemolymph of the desert locust, $S$. gregaria so could control in the $5^{\text {th }}$ nymphal instar and kill them this gave the biological control importance in the control of the nymphal instar of the desert locust. 


\section{REFERENCES}

Al-Aidroos, K. and Seifert, A. M. (1980). Polysaccharide and protein degradation, germination and virulence against mosquitoes in the entomopathogenic fungus Metarhizium anisopliae. Journal of Invertebrate Pathology, 36: 29-34.

Bateman, R.; Carey, M.; Moore, D. and Prior, C. (1993). The enhanced infectivity of Metarhizium anisopliae var acridum oil Formulations to desert locusts at low humidities. Annals of Applied Biology, 122: 145152.

Boucias, D. G. and Pendland, J. C. (1984). Nutritional requirments for conidial germination of sereval host range pathotypes of the entomopathogenic fungus, Nomuraea riley. Journal of Invertebrate Pathology, 43: 288-292.

Cheeseman, P. and Goldsworthy, G. J. (1979). The release of adipokinetic hormone during flight and starvation in Locusta migratoria. Genetic Comparative Endocrine, 37: 35-43.

Cobb, B. (1996). Strategies for carbon metabolism by the entomopathogenic fungus Metarhizium anisopliae. Ph.D. Thesis, University of Bath, Bath, UK. PP 263.

Domnas, A. J. and Warner, S. A. (1991). Biochemical activities of entomopathogenic fungi. Critical Review Microbiology, 18: 1-13.

Driver, F.; Milner, R. J. and Trueman, W. H. (2000). A taxonomic revision of Metarhizium based on a phylogenetic analysis of ribosomal DNA sequence data. Mycology Research, 104: 135-151.

El-Gawhary, H. M. A. (1997). Biochemical effect of some insect growth regulators. M. Sc. Thesis, Fac. Agric., Cairo Univ., Egypt.

Gillespie, J. P.; Andy, M. B.; Bencobb and Andreas, V. (2000a). Fungi as elicitors of insect immune response. Archives of Insect Biochemistry and Physiology, 44: 49-68.

Gillespie, J. P.; Glaire, B. A. and Charnley, K. (2000b). The immune response of the desert locust, Schistocerca gregaria during mycosis of the entomopathogenic fungus, Metarhizium anisopliae var acridum. Journal of insect physiology, 46: 429-437.

Goldsworthy, G. J. and Mordue, W. (1973). The effects of corpora cardiaca on tethered flight in the locust. Journal of Comparative Physiology, 82: 359-368.

Gornall, A.; Barswell, C. and David, M. (1949). Determination of Serum protein by means of the Biuret reaction. Journal of Biochemistry, 177: 751-766. 


\section{Eid, M. A. A. et al.}

Gurwattan, S. M.; Michael, J. B. and George, G. K. (1991): Morphology and cytochemestry of haemocytes and analysis of haemolymph from Melanoplus sanguinipes (Orthoptera: Acrididae). Journal of Economic Entomology, 84(2): 371-378.

Hua, Z.; Zhong-kang, W.; You-ping, Y.; Yan-ling, L.; Zhenlun, L.; Guo-xiong, P. and Yu-xian, X. (2007). Trehalose and trehalose hydrolyzing enzyme in the haemolymph of L ocusta migratoria infected with Metarhizium anisopliae strain CQMa- 102. Insect Science, 14(4): 277282.

Johnson, D. L.; Huang, H. C. and Harper, A. M. (1988). Mortality of grasshoppers inoculated with a Canadian isolate of the fungus, Verticillium lecanii. Journal of Invertebrate Pathology, 52: 335-342.

Knight, J. A.; Anderson, S. and Rawle, J. M. (1972). Chemical basis of the sulfo-phospho-vanillin reaction for estimating total serum lipids. Clinic Chemistry, 18:199-202.

Latge, L. S.; Brey, P. And Diaquin, M. (1987). Non specific induction of germination of Conidiobolus obscurua and Nomuraea rileyi with host and host cuticle extracts. Journal of Invertebrate Pathology, 40: 274278.

Lockwood, J. A. and Ewen, A. B. (1997). Biological control of rangeland grasshoppers and locusts in the bionomics of grasshoppers. Katydids and Their Kin, ed. SK Gang were, MC Muralingan, Mualingan, pp. 421442. Wallingford, England, CAB INT.

Mettaweh, H. H.; Gomma, E. A. A.; Sherif, R. M. and Abd El- Fattah, T. A. (2001a). Three entomopathogenic fungi and their effect on some biological aspects of the grasshopper, Euprepocnemis plorans plorans Charpenter (Orthoptera: Acrididae). Egyptian Journal of Biological Pest Control, 11(2): 165-175.

Polanowski, A.; Blum, M. S.; Whitman, D. W. and Travis, J. (1997). Proteinase inhibitors in the nonvenomous defensive secretion of grasshoppers: antiproteolytic range and possible significance. Comparative Biochemistry and Physiology B, Biochemistry and Molecular Biology, 117(4): 525-529.

Prior, C. J. and Greathead, D. J. (1989). Biological control of locusts: The potential for the exploitation of pathogens. FAO Plant Protection Bullent, 37: 37-48.

Rees, H. H. (1985). Biosynthesis of ecdysone, in comprehensive Insect Physiology, Biochemistry and Pharmacology. Pergam on press, Oxford, pp: 249-294.

Richmond, W. (1973). Preparation and properties of cholesterol oxidase from Nocardia sp. and its application to the enzymatic assay of total cholesterol in serum. Clinic chemistry, 19: 1350-1356.

Robert, M. O.; Andrena, K.; Goettel, M. S.; Jacques, B. and Michael, J. B. (2002). Attenuation of fungal infection in thermoregulating Locusta migratoria is accompanied by changes in haemolymph proteins. Journal of Invertebrate Pathology, 81: 19-24. 
Sewify, G. H. and Moursy, E. B. (1993). impact of the entomopathogenic fungus, Verticillium lecanii on lipid and free fatty acids of cabbage aphid, Brevicoryne brassicae. Bullent Entomology Society Egypt, 71: 153-162.

Seyoum, E.; Bateman, R. P. and Charnley, A. K. (2002). The effect of Metarhizium anisopliae var acridum on haemolymph energy reserves and flight capability in the desert locust, Schistocerca gregaria. Journal of Applied Entomology, 126: 119-124.

Seyoum, E.; Moore, D. and Charnley, A. K. (1994). Reduction in flight activity and food consumption by the desert locust, Schistocerca gregaria after infection with Metarhizium flavoviridae. Zoology Angew Entomology, 118: 310-315.

Showler, A. T. and Potter, C. S. (1991): Snopsis of the 1986- 1989 desert locust (Orthoptera: Acrididae) plague and the concept of strategic control. American Entomology, 37: 106-110.

Steel, J. E. and Hall, S. (1985). Trehalose synthesis and glycogenolysis as sites of action for the corpora cardiacum in Perplaneta Americana. Insect Biochemistry, 15: 529-536.

Trinder, P. (1969). Enzymatic determination of sugars in serum and plasma. Annual Clinic Biochemistry, 6: 24.

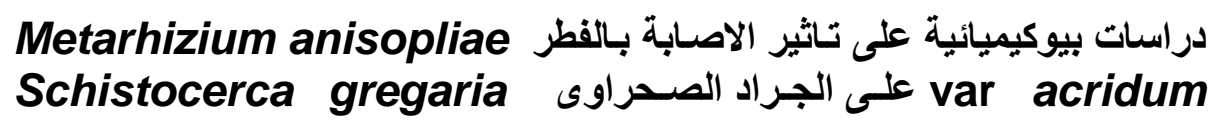
Forskal

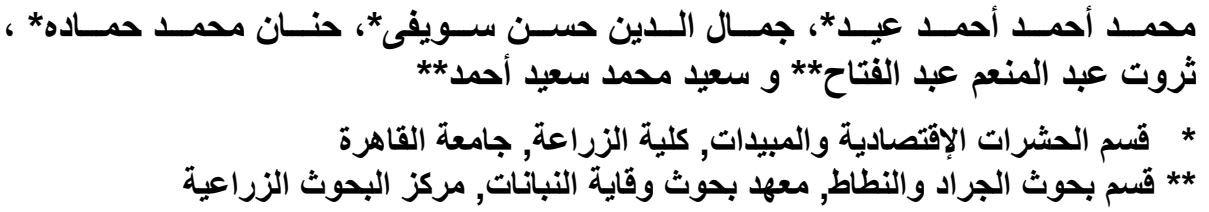

